\title{
PAKTA INTEGRITAS DI TENGAH SURAMNYA PEMBERANTASAN TINDAK PIDANA KORUPSI DI INDONESIA
}

\begin{abstract}
Ahmad Basuki
Fakultas Hukum

Universitas Wijaya Kusuma Surabaya

Abstrak

Korupsi di Indonesia saat ini mengindikadikan sistemik, endemik, dan dianggap mengancam terhadap kepercayaan publik (public trust) terhadap kinerja pemerintahan, sehingga upaya pemberantasannya telah dilakukan melalui cara-cara yang istimewa (extra-ordinary measures). Belum optimalnya perbaikan komponen legal substance dan legal structure mendorong Presiden untuk mengintervensi perbaikan legal culture terhadap aspek perilaku dan performen pejabat publik dalam bentuk Pakta integritas dengan digulirkannya Instruki Presiden Nomor 5 Tahun 2004. Namun demikian kebijakan Presiden yang terkesan sporadis, dan tidak konsisten dalam penerapan dan penegakannya telah memperpanjang problem pemberantasan korupsi di Indonesia.
\end{abstract}

Kata Kunci :

\begin{abstract}
Corruption in Indonesia is currently systemic, endemic, and considered threatening to public trust (public trust) on the performance of government, so that eradication efforts have been made??through special ways (extra-ordinary measures.) Component repair is not optimum legal structure and legal substance to encourage the President to intervene in the improvement of legal culture and performen behavioral aspects of public officials in the form of integrity pact with Instruki No. 5 of 2004. The policies of President who impressed sporadic, and inconsistent in application and enforcement has extended the problem of combating corruption in Indonesia
\end{abstract}

Keywords: Integrity Pact, Corruption

\section{PENDAHULUAN}

Penanganan kasus korupsi di KPK sejak tahun 2006, mengejutkan banyak orang, karena kasus tindak pidana korupsi yang melibatkan pejabat publik seperti suap, gratifikasi, dan penyalahgunaan kekuasaan mulai banyak terungkap. Hal ini membuktikan bahwa di era reformasi prinsip good governence dengan pilar negara, swasta dan masyarakat madani masih merupakan kendala yang cukup memprihatinkan untuk diwujudkan. Tidak mengherankan apabila Corruption Perception Index Indonesia masih sangat rendah. Demikian pula Global Competitivness Index yang rendah, karena apa yang dinamakan Ethics and Corruption (public trust of politicians and diversion of public funds, dan favouritism in decision of government officials) sangat diperhitungkan. 
Sebagai contohnya, dapat disebutkan kasus Ramadhan Rizal (Panitera Pengadilan Tinggi DKI Jakarta), kasus M. Soleh (Panitera Muda Pidana Pengadilan Tinggi DKI Jakarta), kasus Sriyadi, Suhartoyo, Sudi Ahmad dan Pono (Karyawan Mahkamah Agung), Kasus Irawady Junus (Anggota Komisi Yudisial), kasus Urip Gunawan (Jaksa di Kejaksaan Agung), kasus Bordju Ronin (jaksa), kasus Cecep Sunarto (jaksa) dan akhir-akhir ini sedang ditangani KPK adalah kasus DGS Bank Indonesia yang melibatkan para politisi Senayan, dll. Dengan demikian lengkaplah kasus-kasus yang melibatkan komponen dari eksekutif, legislatif maupun judikatif maupun oknum dari berbagai sektor swasta.

Keterlibatan berbagai pejabat publik pemerintahan dalam berbagai kasus korupsi melahirkan dimensi baru di dunia kejahatan. Sebagaimana yang dibahas dalam Konggres PBB VII tentang “The Prevention of Crime and the Treatment of Offenders" di Milan 1985, yang menyoroti tentang meningkatnya "penyalahgunaan kekuasaan" (abuse of power) oleh pejabat yang semakin meluas dan dikenal sebagai korupsi sistemik, yang kadang dimaknai representasi kelembagaan negara, sehingga sering dikatakan pula sebagai "korupsi kelembagaan". Penyalahgunaan kekuasaan di bidang ekonomi dengan melibatkan pihak-pihak "upper economic level" (seperti konglomerat), maupun upper power level (pejabat tinggi) yang berkonspirasi dan bertujuan untuk menguntungkan kepentingan ekonomi kelompok tertentu dan merugikan ekonomi negara dan masyarakat.

Korupsi yang dilakukan dengan berkonspirasi antara upper economic level dengan upper power level yang menggerogoti dana-dana publik (embezzlement of public fund) sering disebut sebagai inti (core) atau bentuk dasar dari tindak pidana korupsi. Sekalipun secara akademik definisi korupsi sangat bervariasi, namun korupsi sendiri secara universal diartikan sebagai kebejatan moral, perbuatan yang tidak wajar, atau noda (depravity, pervertion or taint) dan mengindikasikan suatu perusakan terhadap integritas, kebajikan, atau asas-asas moral (an impairman of integrity, virtue, or moral principle) (Muladi, 2010;3).

Bagi Indonesia yang sejak tahun 1998 memasuki era reformasi, menunjukkan adanya perkembangan korupsi yang semakin kronis dan bersifat sistemik dan endemik, sehingga banyak kalangan menganggap korupsi sebagai tindak pidana yang mengancam terhadap kepercayaan publik (public trust) terhadap kinerja pemerintahan. Oleh karena itu tidak berlebihan apabila korupsi sudah dianggap sebagai salah satu Ahmad Basuki 
bentuk kejahatan luar biasa (extra- ordinary crime), bahkan mantan Presiden Bank Dunia Wolfensohn menyebut korupsi sebagai "the cancer of developing contries (Muladi, 2010: 9). Sehubungan dengan hal tersebut, maka salah satu agenda reformasi yang harus segera dituntaskan antara lain adalah pemberatasan korupsi melalui strategi dan sarana yang luar biasa pula (extra- ordinary measures).

Rencana Pembangunan Jangka Menengah nasional (RPJMN) 20102014 menegaskan misi: Indonesia Sejahtera, Demokratis dan Berkeadilan. Kata "berkeadilan" dimaksud mengandung makna keharusan untuk memperkuat penegakan hukum dan pemberantasan korupsi serta pengurangan kesenjangan.

Berbagai langkah reformasi untuk mencapai tujuan tersebut telah dilakukan, pertama: reformasi pada tataran substansi hukum (legal substance) telah dibangun untuk memberantas KKN dan menciptakan Penyelenggaraan Negara yang bersih dan bebas dari KKN dengan diterbitkannya Ketetapan MPR No. XI/MPR/1998 dan Undang-undang No. 28 Tahun 1999; diundangkannya Undang-undang No. 31 Tahun 1999 Jo. Undang-undang No. 20 tahun 2001 tentang Pemberantasan Tindak pidana Korupsi; Undang-undang No. 15 Tahun 2002 Jo. Undang-undang No. 25 Tahun 2003 Tindak Pidana Pencucian
Uang serta Undang-undang No. 30 tahun 2002 tentang Pembentukan Komisi Pemberantasan Tindak Pidana Korupsi disertai berbagai Instrusi Presiden untuk percepatan pemberantasan korupsi seperti pembentukan TIMTASTIPIKOR yang langsung dipimpin oleh Presiden. Bahkan Indonesia juga telah meratifikasi "United Nations Convention Against Transnational Organized Crime, 2000 (Palermo Convention), serta United Nations Convention Against Corruption, 2003 (Merida Convention). Kedua: reformasi pada tataran struktur hukum (legal structure), disamping telah dibentuk Komisi Pemberantasan Korupsi (KPK) atas dasar Undang-undang No.30 Tahun 2002, dimungkinkan pula pembentukan Pengadilan Tindak Pidana Korupsi yang semula bersifat khusus (Pengadilan Ad Hoc), namun atas dasar Keputusan Mahkamah Konstitusi nantinya akan ditempatkan di bawah naungan pengadilan umum yang bersifat khusus. Belum lagi pembentukan berbagai komisi di lingkungan lembaga penegakan hukum, seperti Komisi Kepolisian, Komisi Kejaksaaan, Komisi Yudisial, dan terakhir dengan dibentuknya Satuan Tugas (Satgas) Pemberantasan Mafia Hukum.

Kemajuan yang cukup signifikan di bidang substansi dan struktur hukum di atas, nampaknya belum diimbangi dengan perkembangan budaya hukum 
(legal culture) dan kualitas moral sumberdaya manusianya, yang belum sepenuhnya dapat meresapi dan memenuhi tuntutan dan semangat reformasi. Hal ini terlihat dari lambannya penanganan kasus-kasus korupsi yang dilakukan atau melibatkan para pejabat yang secara administratif memang diberikan kewenangan dan sarana untuk melakukan atau tidak melakukan sesuatu sesuatu yang terkait dengan jabatannya. Keterbatasan rumusan pasal 3 Undang-undang No. 31 Tahun 1999 mengenai makna dan kriteria "menyalahgunakan kewenangan" yang secara administratif bukan sebagai domein peradilan untuk menilainya, seringkali menjadi batu sandungan dalam pembuktian di pengadilan.

Pasal 3 Undang-undang No. 31

Tahun 1999 antara lain menyatakan:

"setiap orang yang dengan tujuan menguntungkan diri sendiri atau orang lain atau suatu korporasi, menyalahgunakan kewenangan, kesempatan atau sarana yang ada padanya karena jabatan atau kedudukan yang dapat merugikan keuangan negara atau perekonomian negara dipidana penjara ...dst"

Secara doktriner, makna unsur "menyalahgunakan wewenang" tidaklah sama dengan unsur "melawan hukum", khususnya terhadap pemahaman kajian hukum pidana korupsi. Implikasi makna tersebut adalah, bahwa penyalahgunaan wewenang adalah tersirat sebagai melawan hukum (meskipun menimbulkan perdebatan yang panjang, apakah melawan hukum ini diartikan dalam arti formil atau termasuk juga dalam arti materiil), namun demikian tidaklah berarti memenuhi unsur "melawan hukum", berarti pula memenuhi unsur "menyalahgunakan wewenang". Kedua unsur itu jelas berbeda, baik dari sisi "materiele feit" maupun "strafbarfeit", karena itu penempatan kedua ketentuan merupakan pasal-pasal yang terpisah dalam Undang-undang tindak pidana korupsi di Indonesia (Indriyanto Seno Adji, 2009:441).

Disparitas/ dualisme pengertian dan domein sifat melawan hukum dari unsur "menyalahgunakan wewenang" dalam pasal 3 Undang-undang No. 31 Tahun 1999 (sebagai kontens administratif atau kontens peradilan) semakin menambah beban berat bagi misi reformasi untuk mewujudkan birokrasi dan pemerintahan yang bersih dari korupsi, dan bahkan memberikan kesan impunity, untouchable bagi para pejabat yang secara empirik nyata bisa dirasakan adanya unsur penyalahgunaan wewenang, tetapi secara teknis-yuridis menghadapi kesulitankesulitan dalam hal pembuktiannya.

Akuntabilitas Kebijakan dalam rangka good and clean governance masih jauh dari yang diharapkan, yang pada akhirnya tidak akan mampu meminimalkan index korupsi bahkan justru sebaliknya. Sebagaimana formula yang dirumuskan 
oleh Robert Klittgard (Muladi, 2010; 13), bahwa $: C$ (orruption $)=M($ onopoly $\mathrm{Ke}$ kuasaan $)+D$ (iscretion) $-A($ ccountability) . Artinya apabila berkeinginan secara serius untuk melakukan pencegahan dan pemberantasan korupsi, maka faktor $\mathrm{M}$ (monopoli kekuasaan) dan Penyelenggaraan D (diskresi) harus diawasi, serta meningkatkan A (akuntabilitas) nya.

Sesuai dengan formula Klittgard, maka Presiden telah mengambil langkahlangkah strategis untuk mempercepat upaya pemberantasan tindak pidana korupsi melalui Instruksi Presiden Nomor 5 tahun 2004. Secara garis besar melalui instruksi tersebut Presiden sebagai Kepala Pemerintahan memerintahkan seluruh lini jaring pemerintah untuk memperkuat komitment memerangi korupsi dalam bentuk Pakta Integritas. Permasalahan yang menarik untuk dikaji dalam tulisan ini adalah bagaimana efektifikatas penegakan Pakta Integritas tersebut dilihat dalam konteks ketatanegaraan dan pemberantasan korupsi

\section{Konsepsi Negara Hukum Indonesia}

Negara Republik Indonesia adalah suatu Negara hukum yang berdasarkan Pancasila. Pancasila sebagai dasar Negara yang mencerminkan jiwa bangsa Indonesia dalam semua aturan hukum dan pelaksanaannya. Sistem pemerintahan Negara sebagaimana yang tertera dengan jelas dan sistematis dalam Undang-undang Dasar 1945 (pra amandemen) mengandung tujuh pokok pikiran, yang pada Bagian Pertama menyatakan: "Indonesia adalah negara yang berdasar atas hukum (Rechtstaat), tidak berdasarkan atas kekuasaan (machtstaat)". Sepintas Penjelasan Undang-undang Dasar 1945 tersebut mengandung pertanyaan yang kontroversial, karena statement yang begitu fundamental hanya dirumuskan dalam bab penjelasan, dan dalam Batang Tubuh Undang-undang Dasar 1945 sendiri tidak ditemukan satu kalimat pun yang menegaskan bahwa Indonesia adalah Negara Hukum. Kontroversi tersebut kini pupus setelah Undang-undang Dasar 1945 hasil Amandemen menegaskan dalam Pasal 1 ayat (3) bahwa: Negara Indonesia adalah negara hukum.

Penjelasan konsepsi negara hukum Indonesia, ialah suatu Negara dimana perseorangan mempunyai hak terhadap negara. Hak-hak diikuti oleh undang-undang, dimana untuk merealisir perlindungan terhadap hak asasi manusia itu kekuasaan negara harus dipisahkan sehingga badan penyelenggara, badan pembuat undang-undang dan badan peradilan berada pada pelbagai tangan satu sama lain, dengan susunan badan peradilan yang bebas kedudukannya untuk dapat memberi perlindungan yang semestinya kepada setiap orang yang 
merasa hak-haknya dirugikan, walaupun andai kata hal itu terjadi oleh alat Negara sendiri. Jadi dalam suatu Negara hukum, hukumlah yang menjadi "panglima", hukum yang menjadi supremasi, yang memerintah adalah adalah hukum (the rule of law). Negara beserta aparatur dan jajarannya dalam melaksanakan tugas negara harus dilandasi hukum dan harus dipertanggungjawabkan secara hukum, bukan sekedar kekuasaan (macht).

Hakekat dari sistem yang dianut Negara ini, tercermin dalam rumusan Pasal-pasalnya yang merupakan keselarasan dari pelaksanaan pokok-pokok pikiran yang terkandung dalam Pembukaan Undang-undang Dasar 1945, yang kemudian diwujudkan dalam citacita hukum (rechtsidee) dengan menjiwai Undang-undang dasar 1945 dan hukum yang tidak tertulis. Dengan demikian jelaslah bahwa negara hukum yang dicita-citakan bukan sekedar Negara hukum dalam arti formal. Juga bukan hanya berarti Negara yang berfungsi sebagai "polisi lalu lintas" atau "penjaga malam" saja, yang menjaga jangan sampai terjadi pelanggaran hukum lalu kemudian menindak pelanggaran tersebut. Pengertian Negara hukum yang dicita-citakan, adalah Negara hukum dalam arti luas, yakni Negara hukum dalam arti materiil. Negara bukan hanya melindungi segenap bangsa Indonesia dan seluruh tumpah darah Indonesia, tetapi juga harus memajukan kesejahteraan umum dan mencerdaskan kehidupan bangsa sebagaimana yang diamanatkan dalam Pembukaan Undang-undang Dasar 1945.

Negara Hukum dalam arti materiil itu, dimaksudkan agar segala tindakan Negara termasuk alat kelengkapan dan aparaturnya haruslah senantiasa mempertimbangkan dua macam landasan kepentingan, yaitu landasan hukumnya (rechtsmatigheid), dan kegunaannya (doelmatigheid). Setiap kebijakan, tindakan dan keputusan yang diambil oleh penyelenggara negara mesti diusahakan serasi dan selaras untuk memenuhi kepentingan tersebut (Ahmad Basuki, 2007;126129).

\section{Freies Ermessen dalam Negara Hukum Materiil}

Secara bahasa freies ermessen berasal dari kata frei yang artinya bebas, lepas, tidak terikat, dan merdeka. Freies artinya orang yang bebas, tidak terikat, dan merdeka. Sementara itu, ermessen berarti mempertimbangkan, menilai, menduga dan mempertimbangkan sesuatu. Istilah ini kemudian secara khas digunakan dalam bidang pemerintahan sehingga freies ermessen (diskretionare) 
diartikan sebagai salah satu sarana yang memberikan ruang bergerak bagi pejabat atau badan-badan administrasi negara untuk melakukan tindakan tanpa harus terikat sepenuhnya pada undang-undang (Marcus Lukman, 1996;205).

Pengertian lain yang semakna diberikan oleh Nata Saputra, menurutnya freies ermessen adalah suatu kebebasan yang diberikan kepada alat administrasi, yaitu kebebasan yang pada asasnya memperkenankan alat administrasi negara mengutamakan tercapainya suatu tujuan (=doelmatigheid) dari pada berpegang teguh kepada ketentuan hukum (Nata Saputra, 1988;15). Pendek kata freies ermessen merupakan kewenangan yang sah untuk turut campur dalam kegiatan sosial guna melaksanakan tugas-tugas menyelenggarakan kepentingan umum (SF Marbun dan Moh. Mahfud, 1987; 46).

Maksud diberikannya freies ermessen kepada pemerintah, menurut Bahsan Mustafa terkait dengan fungsi pemerintah atau administrasi negara, yaitu menyelenggarakan kesejahteraan umum yang berbeda dengan fungsi kehakiman untuk menyelesaiakan sengketa antar penduduk. Keputusan pemerintah lebih mengutamakan pencapaian tujuan atau sasarannya (doelmatigheid) daripada sesuai dengan hukum yang berlaku (rechtmatigheid) (Bahsan
Mustafa, 1990;55).

Konsep freies ermessen ini muncul sebagai alternatif untuk mengisi kekurangan dan kelemahan dalam penerapan asas legalitas (wetmatigheid van bestuur). Bagi negara yang menganut konsep negara welfare state atau negara hukum materiil termasuk di dalamnya Indonesia, asas legalitas saja tidak cukup untuk dapat berperan secara maksimal dalam melayani kepentingan masyarakat yang berkembang pesat sejalan perkembangan ilmu pengetahuan dan teknologi seperti sekarang ini.

Meskipun pemerintah diberikan kewenangan bebas atau freies ermessen, tetapi dalam suatu negara hukum penggunaan fries ermessen harus dalam batas-batas yang dimungkinkan oleh hukum yang berlaku. Penggunaan freies ermessen tidak boleh bertentangan dengan hukum yang berlaku, baik hukum yang tertulis maupun yang tidak tertulis. Menurut Muhsan penggunaan freies ermessen tidak boleh bertentangan dengan sistem hukum yang berlaku (kaidah hukum positif) serta hanya ditujukan demi kepentingan umum (Muhsan, 1981;28).

$$
\text { Sedangkan Sjachran Bash }
$$
berpendapat bahwa pelaksanaan freies ermessen harus dapat dipertanggungjawabkan, secara moral kepada Tuhan 
Yang maha Esa, menjunjung tinggi harkat dan martabat manusia, serta nilainilai kebenaran dan keadilan, mengutamakan persatuan dan kesatuan demi kepentingan bersama (Sjachran Basah, $1985 ; 151)$.

Lebih lanjut beliau menegaskan bahwa secara hukum terdapat dua batasan penggunaan freies ermessen, yaitu batas atas dan batas bawah. Batas atas dimaksudkan ketaat-asasan pada ketentuan perundang-undangan. Berdasarkan asas "taat-asas", yaitu peraturan yang derajatnya lebih rendah tidak boleh bertentangan dengan peraturan yang derajatnya lebih tinggi. Sementara itu, batas bawah adalah peraturan yang dibuat atau sikap tindak administrasi negara (aktif maupun pasif), tidak boleh melanggar hak dan kewajiban asasi warga (Sjachran Basah, 1992; 4-5).

\section{Pakta Integritas dalam Upaya Pemberantasan Korupsi}

Dalam Ensiklopedia Indonesia disebut "korupsi" (dari bahasa latin: corruptio = penyuapan; corruptore-merusak) gejala dimana pejabat, badan-badan negara menyalahgunakan wewenang dengan terjadinya penyuapan, pemalsuan, sereta ketidakberesan lainnya. Adapun arti harfiah dari korupsi dapat berupa: (1)kejahatan, kebusukan, dapat disuap, tidak bermoral, kebejatan dan ketidakjujuran. (2)perbuatan yang buruk seperti penggelapan uang, penerimaan uang sogok, dan sebagainya (W.J.S. Poerwadarminta, 1976: ) (3)menurut Muhamad Ali, korupsi berkaitan dengan: (a)korup (busuk, suka menerima uang suap/ sogok, memakai kekuasaan untuk kepentingan sendiri dan sebagainya); (b)korupsi (perbuatan busuk seperti penggelapan uang, penerimaan uang sogok, dan sebagainya);) (c)koruptor (orang yang melakukan korupsi).

Secara yuridis (undang-undang 31 tahun 1999) pengertian korupsi dapat ditemukan dalam pasal 2 ayat (1), yang mendiskripsikan korupsi sebagai "perbuatan secara melawan hukum memperkaya diri sendiri atau orang lain, atau suatu korporasi yang dapat merugikan keuangan atau perekonomian negara".

Fenomena korupsi sebenarnya sudah terjadi sejak zaman dahulu kala, bahkan mungkin seusia peradaban manusia itu sendiri. Hal ini terungkap dari Hasil temuan Tim Arkeologi Belanda yang menemukan sekitar 150 prasasti "Cunaiform" di Ridka Syria, yang menunjukkan bahwa situs tersebut adalah pusat administrasi peradaban Syria pada abad ke-13 SM. Dalam situs tersebut ditemukan sebuah arsip milik lembaga setara dengan lembaga modern"Kementrian Dalam Negeri" yang berisi nama-nama pegawai yang 
menerima suap termasuk nama-nama pejabat tinggi dan nama seorang putri Assyyria (dikutip dari buku panduan Transparancy International, 2002) (Zudan AriefFahrulloh, 2009;225)

Pada awalnya penyebab utama korupsi adalah kemiskinan, sehingga kemiskinan dianggap sebagai akar dari masalah korupsi. Namun paradigma tersebut mulai bergeser karena ternyata korupsi telah merambah pada sektor swasta (konglomerat) dan birokrat tinggi yang level kehidupannya telah bergelimang dengan kekayaan. Korupsi dengan segala bentuknya di Indonesia saat ini sedah menyerang seluruh sistem sosial yang sedemikian rupa sehingga yang terjangkit adalah sistem secara total. Hampir tak sejengkal ruangpun ketika berhubungan dengan penyelenggaraan pemerintahan yang terbebas dari perbuatan koruptif. Dalam kondisi seperti ini maka menurut Syed Hussen Alatas akan terjadi apa yang disebut pengaruh korupsi yang menular (metastatic) ( $\mathrm{SH}$ Alatas, 1987: xiii).

Meskipun korupsi lekat dalam setiap peradaban manusia, tetapi upaya pemberantasan tetap harus dilakukan, paling tidak membatasinya baik secara kuantitas maupun kualitas. Perjuangan pemberantasan korupsi telah dimulai di era kekuasaan orde lama di bawah kepemimpinan Presiden RI. Soekarno, dan demikian halnya di era kekuasaan orde baru di bawah kepemimpinan Presiden Soeharto. Di Era reformasi upaya pemberantasan korupsi dimulai dengan pembentukan Tim Gabungan Pemberantasan Tindak Pidana Korupsi (TGTPK) melalui Peraturan Pemerintah No. 19 tahun 2000 sebagai tindak lanjut dari diterbitkannya satu paket produk hukum untuk pemberatasan KKN melalui Tap MPR RI No. XI/MPR/1998 dan Undang-undang No. 28 Tahun 1999. Selanjutnya diterbitkan Undang-undang No. 31 tahun 1999 jo. Undang-undang No. 20 tahun 2001 sebagai pengganti Undang-undang no. 3 Tahun 1971 yang dinilai sudah tidak memadai dalam melakukan pemberantasan korupsi. Bahkan secara khusus Pemerintah telah mengeluarkan Peraturan Pemerintah No. 68 tahun 1999 yang memberikan akses bagi masyarakat untuk berperanserta dalam rangka pemberantasan korupsi dan membentuk Komisi Pemeriksa Kekayaan Penyelenggara Negara (KPKPN) tahun 1999 yang selanjutnya keberadaannya melebur ke Komisi Pemberantasan Tindak Pidana Korupsi (KPTPK) yang selanjutnya disebut Komisi Pemberantasan Korupsi (KPK) berdasarkan Undang-undang No. 30 tahun 2002.

Pembentukan KPK pada tanggal 27 Desember 2003, pada mulanya 
memang memberikan kesan komitmen yang kuat dari pemerintah sekaligus memberikan segudang harapan dalam pemberantasan korupsi.

Keseriusan pemerintahan reformasi dalam memberantas dan menyelesaikan kasus-kasus korupsi sangat beralasan. Pertama, bahwa salah satu tuntutan rakyat dalam aksi reformasi adalah pemberantasan korupsi, disamping tuntutan demokrtisasi dan perlindungan HAM yang selama regime Orde Baru terabaikan. Kedua, bahwa sedemikian kronis dan endemiknya korupsi di semua lini kehidupan bernegara yang sangat merugikan keungan dan kekayaan/ aset negara. Ketiga bahwa efek domino dari sistem yang korup dalah rendahnya kualitas pelayanan publik serta melahirkan hight cost economy yang tidak kompetitif terhadap iklim investasi dan pembangunan ekonomi secara makro.

Setelah sekian tahun waktu berlalu, dan dari satu periode eperiode masa jabatan pimpinan KPK telah dilewati justru menunjukkan indikasi yang sebaliknya. Semakin lama corruption index menunjukkan adaya peningkatan baik dari sisi jumlah (kuantitatif) maupun tingkat kerugian (kualitatif) yang dipikul oleh negara menjadi berlipat. Pembentukan Komisi Pemberatasan Korupsi dengan segala kewenangan yang dimiliki (baca super body) yang diharapkan akan mampu mengembalikan kekayaan negara yang 'dijarah oleh koruptor, tetapi yang terjadi justru sebaliknya, menambah panjang birokrasi yang pada akhirnya menambah beban anggaran negara.

Rumitnya problem penegakan hukum terhadap para pelaku korupsi akhir-akhir ini mendorong pemerintah untuk merubah orientasi pemberantasan korupsi dari orientasi menghukum pelaku dan mengembalikan kerugian negara ke arah pembenahan dan pembinaan birokrasi yang selama ini dianggap sebagai sumber dan biang korupsi.

Perubahan fokus pemberantasan korupsi yang demikian ini tampak dengan digulirkannya Instruksi Presiden No. 5 tahun 2004 tentang Percepatan Pemberantasan Korupsi yang di dalamnya berisi 10 (sepuluh) instruksi umum kepada semua tingkatan dan wilayah pemerintahan, instansi pemerintah pusat dan daerah, serta 11 (sebelas) instruksi khusus kepada instansi khusus.

Instruksi Umum dari Presiden meliputi: kewajiban membuat laporan harta kekayaan penyelenggara negara (LHKPN), membantu KPK dalam pelaporan dan pemeriksaan LHKPN, membuat penetapan kinerja, meningkatkan kualitas pelayanan publik, menetapkan 
program dan wilayah bebas korupsi (dituangkan dalam pakta integritas), melaksanakan Keputusan Presiden No 80 tahun 2003 tentang pengadaan barang / peralatan pemerintah (penerapan $e$ procurement, e-government), menerapkan kesederhanaan hidup, memberikan dukungan maksimal terhadap penindakan korupsi oleh aparat penegak hukum, kerjasama dengan KPK dalam pengkajian sistem yang berpotensi korupsi dan meningkatkan pengawasan dan pembinaan aparatur untuk meniadakan perilaku koruptif.

Sedangkan Instruksi khusus dari Presiden meliputi: kajian dan uji coba penerapan e-procurement (Menko Perekonomian, Menkeu, Men PPN/ Kepala Bappenas), pengawasan perpajakan, kepabeanan dan cukai, PNBP (Penerimaan Negara Bukan Pajak), dan anggaran, untuk menghilangkan kebocoran (Menkeu), Rencana Aksi Nasional Pemberantasan Korupsi atau RAN-PK (MenPPN/Kepala Bappenas), kebijakan peningkatan kualitas pelayanan publik, penetapan kinerja, penerapan prinsip-prinsip tata kepemerintahan yang yang baik, pengkajian sistem kepegawaian negara, dan koordinasimonitoring-evaluasi Inpres ini (Menpan), menyusun amandemen undang-undang pemberantasan tindak pidana korupsi, menyusun peraturan perundang-undangan yang terkait dengan pemberantasan tindak pidana korupsi (Menkumham), implementasi prinsip tata kelola perusahaan yang baik (MenBUMN), pendidikan bersubstansi semangat dan perilaku antikorupsi (Mendiknas), sosialisasi pendidikan antikorupsi dan kampanye anti korupsi (Menkominfo), mengoptimalkan penyidikan, sanksi tegas, dan kerjasama penegakan hukum dan pengembalian kerugian keuangan negara akibat tindak pidana korupsi (Jaksa Agung dan Polri), serta menerapkan prinsipprinsip tata pemerintahan yang baik, pelayanan publik, meniadakan pungutan liar, dan bersama DPR melakukan pencegahan kebocoran keuangan negara, APBN/APBD (Gubernur dan Bupati/Walikota). Sejalan dengan itu semua, tingkatkan akuntabilitas, transparansi, jangan menyalahgunakan wewenang, tegakkan hukum, hilangkan kesempatan dan niat berbuat korupsi.

Sekilas muatan instruksi sangat jelas, dan sistematik dalam rangka mencegah dan membatasi wabah korupsi. Prinsip transparansi birokrasi dan penguatan komitment pejabat publik untuk melaporkan kekayaan sebelum dan sesudah menjabat melalui LHKPN sepertinya akan menjadi strategi jitu dalam menangkal terjadinya korupsi. Sangat disayangkan apabila prinsip tersebut pada kenyataannya sangat sulit dalam hal penegakannya.

Situasi yang demikian sangat mungkin akan terjadi melihat tugas dan 
wewenang untuk melakukan monitoring dan evaluasi terhadap pelaksnaan instruksi berada di tangan kementrian Pendayagunaan Aparatur Negara (Menpan). Secara administratif, Menpan adalah termasuk dalam kategori kementerian negara, yaitu kementrian yang tidak mempunyai kewenangan riil, dan secara politis mempunyai eselon yang lebih rendah dibandingkan kelompok kementrian yang lain (baca kementrian departemen). Dengan demikian memang sangat disayangkan bahwa persoalan monitoring dan evaluasi terhadap pelanggaran Inpres Nomor 5 tahun 2004 diberikan kepada kementrian (negara) Pendayagunaan Aparatur Negara (Menpan).Tidaklah mengherankan apabila diketahui adanya beberapa calon pejabat publik atau bahkan sudah aktif menjabat tetapi belum menyerahkan LHKPN, toh pada akhirnya Kemenpan tidak dapat berbuat banyak. Di samping persoalan mengenai kompetensi Kementrian Pendayagunaan Aparatur Negara dalam melakukan monitoring dan evaluasi terhadap pelaksanaan Inpres, masih ada permasalahan yang dalam Inpres Nomor 5 tahun 2004 yaitu menyangkut tidak terjangkaunya penataan dan reformasi lembaga peradilan yang justru selama ini menjadi trigger utama dalam pem- berantasan korupsi di Indonesia. Mekanisme dan pandangan yang legalpositifistik yang dianut oleh para penegak hukum menjadikan peradilan sebagai tameng dan tempat berlindung bagi koruptor. Beberapa kelemahan yang sifat mendasar baik secara substantif maupun lingkup/ jangkauan dari instruksi presiden tersebut memberikan kesan masih kurang seriusnya komitmen pemerintah dalam pemberantasan korupsi. Sepertinya efektifitas dari pakta integritas dalam rangka pemberantasan korupsi masih jauh dari yang diharapkan. Quo vadis pemberantasan korupsi di Indonesia.

\section{PENUTUP}

Berdasarkan uraian tersebut di atas dapat dikemukakan beberapa kesimpulan sebagai berikut: (1)korupsi di Indonesia saat ini menunjukkan adanya perkembangan korupsi yang semakin kronis dan bersifat sistemik dan endemik, sehingga banyak kalangan menganggap korupsi sebagai tindak pidana yang mengancam terhadap kepercayaan publik (public trust) terhadap kinerja pemerintahan. Oleh karena itu tidak berlebihan apabila korupsi sudah dianggap sebagai salah satu bentuk kejahatan luar biasa (extra- ordinary crime), yang mengancam tata kehidupan bermasyarakat dan bernegara (the cancer of developing 
contries). (2)upaya pemberantasan melalui cara-cara yang istimewa (extra-ordinary measures), dengan tetap mengacu pada prinsip-prinsip negara hukum (doelmatigheid), seperti pembuatan perangat peraturan-perundangan yang represif dan keras, serta pembentukan KPK yang super body, dipandang tidak cukup manakala tidak dibarengi dengan pembinaan moral dan integritas. Faktor pembenahan legal cultur sangat diperlukan. (3)penguatan integritas pejabat publik yang diinstruksikan oleh Presiden melalui pakta integritas pejabat belum dapat maksimal, karena monitoring dan evaluasinya ditugaskan kepada Kementrian (negara) Pendayagunaan Aparatur Negara yang secara administratif ketatanegaraan tidak mempunyai kompetensi yang sempurna. (4)sangat disayangkan kebijakan presiden dalam upaya melakukan percepatan dalam pemberatasan korupsi tidak menyentuh pada lembaga yang selama ini menjadi kendala dalam penegakan hukum yaitu sektor peradilan (Mahkamah Agung).

\section{DAFTAR PUSTAKA}

Ahmad Basuki, (2007). Kebijakan Rektroaktif Dalam Penegakan Hukum Terhadap Pelanggaran Hak Asasi Manusia yang Berat, Majalah PERSPEKTF Keadilan
(Vol. XII No. 2 Edisi Mei 2007)

Bahsan Mustafa, (1990). Pokok-pokok Hukum Administrasi Negara, Bandung, Citra Aditya Bakti

Indriyanto Seno Adji, (2009). Korupsi, Kebijakan Aparatur Negara dan Hukum Pidana, Jakarta, Kantor Konsltas Hukum Oemar Seno Adji \& Rekan

Marbun SF dan Moh. Mahfud, (1987). Pokok-pokok Hukum Administrasi Negara, Yogyakarta

Marcus Lukman, (1996). Eksistensi Peraturan Kebijaksanaan dalam Bidang Perencanaan terhhadap Pembangunan di Daerah sertaDampaknya terhadap Pembangunan Materi Hukum Tertulis Nasional, Disertasi, Universitas Padjadjaran, Bandung

Muhsan, (1982). Beberapa Catatan tentang Hukum Administrasi Negara Indonesia, Yogyakarta

Muladi, (2010). Tindak Pidana Suap sebagai Core Crime Mafia Peradilan d an Penanggulangannya, Makalah Seminar "Suap, Mafia Peradilan, Penegakan Hukum dan Pembaharuan Hukum Pidana (Kerjasama FH UNDIP dan Komisi Yudisial RI)
Muhammad Ali, Kamus Lengkap Bahasa Indonesia Modern, Jakarta, Pustaka Amani 